\title{
Climate Change Law (2020)
}

\author{
Rosemary Lyster*
}

In this chapter, the efforts of the international community to deal with climate change and climate-induced disasters is discussed and analysed through the lens of the 1992 United Nations Framework on Climate Change (UNFCCC), ${ }^{1}$ the 2015 Paris Agreement ${ }^{2}$ and the accompanying Decision 1/CP.21 ${ }^{3}$ to implement the Agreement. An analysis of progress since Paris will be offered. However, at the time of writing, the world is facing a number of unprecedented challenges - a climate emergency, a global pandemic emergency, and an ongoing economic emergency carrying over from 2019. This chapter, which updates International Disaster Law relating to climate change in 2020 , assesses how the international community is dealing with the climate emergency, and foreshadows the consequences of the pandemic and the economic crisis for action on climate change.

\section{1 \\ The Climate Emergency and the Best Available Scientific Evidence}

The Oxford English Dictionary selected the term 'climate emergency' as its word for 2019. It defined it as 'a situation in which immediate action is needed to reduce or stop climate change and prevent serious and permanent damage to the environment'. ${ }^{4}$

When alluding to the best available scientific evidence, a plethora of reports have been produced by the Intergovernmental Panel on Climate Change. In 2012, the (IPCC) Working Group II (WGII) released a Special Report Managing the Risks of Extreme Events and Disasters to Advance Climate Change Adaptation (SREX). ${ }^{5}$ The risk of extreme events, influenced increasingly by climate change, was confirmed in the IPCC's Fifth Assessment Reports including

\footnotetext{
* Professor of Climate and Environmental Law, The University of Sydney Law School and Co-Director of the Australian Centre for Climate and Environmental Law. Professor Lyster is also a key researcher at the University's interdisciplinary Sydney Environment Institute.

1 Available at $<$ http://unfccc.int/files/essential_background/background_publications_htmlpdf/ application/pdf/conveng.pdf $>$, last accessed (as any subsequent URL) on 27 July 2021.

2 Available at <https://unfccc.int/resource/docs/2015/cop21/eng/logro1.pdf >.

3 Available at <http://unfccc.int/resource/docs/2015/cop21/eng/1oao1.pdf>.

4 See $<$ https://www.oxfordlearnersdictionaries.com/definition/english/climate-emergency $>$.

5 Available at <http://www.ipcc-wg2.gov/SREX/images/uploads/SREX-All_FINAL.pdf >.
} 
Working Group I's Report Climate Change 2013: The Physical Science Basis, ${ }^{6}$ and WG II's Report Climate Change 2014: Impacts, Adaptation and Vulnerability. ${ }^{7}$ In 2018, the IPCC's Global Warming of $1.5^{\circ} \mathrm{C}$ Report (the $20181.5^{\circ} \mathrm{C}$ Report) ${ }^{8}$ estimated that global temperatures have already risen approximately $1.0^{\circ} \mathrm{C}$ above pre-industrial levels due to human activities. If this continues, global warming is likely to reach $1.5^{\circ} \mathrm{C}$ between 2030 and $205^{2}$ ('high confidence'). ${ }^{9}$

The IPCC's 2019 Special Report on Climate and Land ${ }^{10}$ (the 2019 Land Report) states that 'climate change, including increases in frequency and intensity of extremes, has adversely impacted food security and terrestrial ecosystems as well as contributed to desertification and land degradation in many regions.'11 Also, '[a]t the regional scale, changing land conditions can reduce or accentuate warming and affect the intensity, frequency and duration of extreme events. ${ }^{12}$ Meanwhile, its 2019 Special Report on the Ocean and Cryosphere in a Changing Climate ${ }^{13}$ (the 2019 Ocean and Cryosphere Report) states that 'over the last decades, global warming has led to widespread shrinking of the cryosphere, with mass loss from ice sheets and glaciers ('very high confidence'), reductions in snow cover ('high confidence') and Arctic sea ice extent and thickness, and increased permafrost temperature, which all exacerbate extreme events ('very high confidence').'.

At the same time, the 2019 IPBES 'Global Assessment on Biodiversity and Ecosystem Services' now warns that the decline in biodiversity is unprecedented and that unless action is taken to reduce the intensity of drivers of biodiversity loss, around 1 million species already face extinction, many within decades. ${ }^{15}$

More recently, 11,0oo climate scientists announced that '[s]cientists have a moral obligation to clearly warn humanity of any catastrophic threat and to "tell it like it is" ... [w]e declare clearly and unequivocally that planet Earth is

Available at $<$ https://www.ipcc.ch/report/ar5/wg1/>.

IPCC, Summary for Policymakers, available at <https://www.ipcc.ch/srccl/chapter/ summary-for-policymakers/>.

Available at $<$ http://www.ipcc.ch/report/sri5/>.

Available at <https://www.ipcc.ch/site/assets/uploads/sites/2/2019/o6/SR15_Headline -statements.pdf>.

Available at $<$ https://www.ipcc.ch/srccl/>.

See IPCC (n 7) para. A.2.

Ibid., para. A.4.

Available at $<$ https://www.ipcc.ch/srocc/ $>$.

See IPCC, Summary for Policymakers available at <https://www.ipcc.ch/srocc/chapter/ summary-for-policymakers/>, para. A.1.

Available at $<$ https://ipbes.net/global-assessment $>$. 
facing a climate emergency'.16 Others warned that 'more than half of the climate tipping points identified a decade ago are now "active", with immediate threats including the loss of the Amazon rainforest and the great ice sheets of Antarctica and Greenland, all of which are currently undergoing measurable and unprecedented changes much earlier than expected. This amounts to an "existential threat to civilisation", which requires an "emergency response". ${ }^{17}$

One would like to think that these warnings about the climate emergency would shock the nations of the world into urgent actions to immediately reduce greenhouse gas emissions and ensure that a target of net zero by 2050 is reached. However, it seems that the ratification of the 2015 Paris Agreement has lulled the world into a false sense of security that the below $2^{\circ} \mathrm{C}$ targets are in place and will be met. At the time of writing, nothing could be further from the truth.

The World Meteorological Organization's State of the Global Climate $2020^{18}$ report notes that in $2019, \mathrm{CO}_{2}$ concentrations reached new highs at $410.5 \pm 0.2$ ppm which is $148 \%$ above pre-industrial levels. Real-time data from specific locations such as Mauna Loa (Hawaii) and Cape Grim (Tasmania) show that in 2020 levels of $\mathrm{CO}_{2}$ continued to increase. ${ }^{19}$

The WMO reports that 2020 was one of the three warmest years on record with the previous six years, including 2020, being the six warmest years on record. At Verkhoyansk, Russian Federation, temperatures reached $38^{\circ} \mathrm{C}$ on 20 June 2020, which was the highest temperature anywhere north of the Arctic Circle. Sea-level rise is accelerating while the ocean's capacity to moderate climate change is diminished with increasing ocean heat storage and acidification. In September 2020, the minimum Arctic sea-ice extent was the second-lowest on record, while the sea-ice retreat in the Laptev Sea was the earliest ever observed by satellite. Currently, Antarctica is losing around 175 to $225 \mathrm{Gt}$ of ice per year. Meanwhile, the 2020 North Atlantic hurricane

16 See William J. Ripple et al., 'World Scientists' Warning of a Climate Emergency' (2020) 70/1 Bioscience 8-12, available at <https://academic.oup.com/bioscience/advance-article/ doi/10.1093/biosci/bizo88/56108o6>.

17 Timothy M. Lenton et al., 'Climate tipping points - too risky to bet against' (2019) 575 Nature 592-6 (amended in 2020), available at <https://www.nature.com/articles/ d41586-019-03595-o>.

18 Available at $<$ https://library.wmo.int/doc_num.php?explnum_id=10618> .

19 Ibid., at 8. 
season was exceptionally active as were extreme heatwaves, severe droughts and wildfires resulting in economic losses of tens of billions of US dollars and many deaths. In the first half of 2020 , approximately 9.8 million displacements were recorded, due to largely hydrometeorological hazards and disasters. ${ }^{20}$

The IFRC World Disasters Report $202 \mathrm{O}^{21}$ provides a sobering warning about the confluence of the CoviD-19 pandemic and climate-induced disasters. It states that between March-September 2020, during the first 6 months of the CoviD-19 pandemic, 100 disasters occurred affecting over $5^{\circ}$ million people. Approximately $99 \%$ of these disasters were extreme climate- and weather-related disasters. ${ }^{22}$

\subsection{The Australian 'Black Summer Fires 2019-2020' Disaster}

In the summer of 2019-2O, southeast Australia suffered a wildfire disaster which received global attention for its scale, ferocity and catastrophic consequences for humans and infrastructure but especially for wildlife. It is because of its horrific impact on native wildlife that this case study is chosen for 2020 , while acknowledging the very serious consequences for humans, especially in developing countries, from the climate-induced disasters in 2020. The Australasian Fire and Emergency Service Authorities Council (AFAC) National Resources Sharing Centre calculated ${ }^{23}$ the area burnt to be 17 million hectares across the states of New South Wales, Victoria, the Australian Capital Territory, Queensland, South Australia and Western Australia. For perspective, this is seven times the area of the Netherlands, for example. Most shockingly, over 3.3 billion vertebrate animals are estimated to have died. ${ }^{24}$ Those that survived faced loss of habitat, food and shelter and increased risk of predation from predators such as red fox and wild cats. ${ }^{25}$ The scale of this disaster caused many people in Australia to experience ecological grief and eco-anxiety. The fires also killed 34 people and another 440 who died afterwards from smoke

$20 \quad$ Ibid., at 5 .

21 IFRC, World Disasters Report 2020, Executive Summary (2020) available at <https:// media.ifrc.org/ifrc/wp-content/uploads/2020/11/IFRC_wdr2020/IFRC_WDR_Executive Summary_EN_Web.pdf $>$.

22 Ibid., at 7.

23 See < https://twitter.com/AFACnews/status/1233262259612213248>.

24 See Chris Dickman, 'Have more than a billion animals perished nationwide this bushfire season? Here are the facts', ABs news (2020), <https://www.abc.net.au/news/2O2O-O1-31/ fact-check-have-bushfires-killed-more-than-a-billion-animals/11912538>.

25 See Chris Dickman, Don Driscoll, Stephen Garnett, David Keith, Sarah Legge, David Lindenmayer, Martine Maron, April Reside, Euan Ritchie, James Watson, Brendan Wintle, John Woinarski, 'After the catastrophe: a blueprint for a conservation response to largescale ecological disaster', Threatened Species Recovery Hub, (January 2020). 
inhalation, razed 5,900 buildings (including 2,779 homes) and will cost more than $\$ 2.1$ billion in insurance, $\$ 4.1$ billion in losses to agriculture and $\$ 4.5$ billion to tourism. ${ }^{26}$

This disaster is explained by the fact that in recent decades, and especially in Australia's southern and eastern regions during spring and summer, there has been a significant increase in the frequency of the most dangerous $10 \%$ of fire weather days. This has led to an earlier start to the southern fire weather season. Climate change is affecting temperature and relative humidity. It also affects the dryness of vegetation as changes in rainfall, air temperature and atmospheric moisture dry the landscape. The fuel load in the landscape is also affected by increased $\mathrm{CO}_{2}$ which can alter the rate and amount of plant growth. Australia has warmed $1.5^{\circ} \mathrm{C}$ since $185^{\circ}$ and the increased frequency and intensity of climate-induced extreme heat also worsens extreme fire weather risk. Of particular concern are dry lightning strikes which occur without significant rainfall and are the main source of natural ignition for bushfires. In some regions of southern Australia, there is a significant increase in days where weather conditions generate thunderstorms within their smoke plumes that are conducive to extreme bushfires. These fire-generated thunderstorms are extremely dangerous. The lightning strikes produced from the smoke plumes of these fires can generate new fires. ${ }^{27} \mathrm{~A}$ large number of ignitions occurred in remote, rugged terrain which were difficult to extinguish early. ${ }^{28}$ Each of these factors alone would increase the fire risk but in combination they amplified the chances of a high-risk fire season. ${ }^{29}$

26 Final Report of the NSw Bushfire Inquiry, available at <https://www.dpc.nsw.gov.au/ assets/dpc-nsw-gov-au/publications/NSW-Bushfire-Inquiry-1630/Final-Report-of-the -NSW-Bushfire-Inquiry.pdf > at 42; Shane Wright, 'Bushfires may crimp living standards long term as insurance costs hit $\$ 2 \mathrm{~b}$, The Sunday Morning Herald (25 January 2020) at <https://www.smh.com.au/politics/federal/bushfires-may-crimp-living-standards-long -term-as-insurance-costs-hit-2b-20200124-p53uen.html>; See also https://en.wikipedia .org/wiki/2019\%E2\%80\%9320_Australian_bushfire_season; and Jack Taylor, 'The Political Economy of Australia's Wildfires' (21 April 2020) at <https://harvardpolitics.com/world/ the-political-economy-of-australias-wildfires/>.

27 See Australian Government - Bureau of Meteorology, 'Special Climate Statement 71 severe fire weather conditions in southeast Queensland and northeast New South Wales in September 2019' (2019) available at <http://www.bom.gov.au/climate/current/state ments/scs71.pdf $>$.

28 See Final Report (n 26) at 35 .

29 Ibid., at 45. 


\section{Mind the Gap between the Rhetoric and the Reality}

In the face of escalating climate-induced disasters and the climate emergency, in 2020 the world seemed to be swept up in calling on countries to commit to net zero by 205о. The вP Statistical Review of World Energy $2020^{30}$ provides a sobering snapshot of primary energy consumption in 2019 (noting that the 2021 report for 2020 is not available at the time of writing but changes to these statistics are likely to be negligible). What this report shows is that $84.3 \%$ of fuel shares of primary energy and contributions to growth in 2019 were fossil fuels $-33.1 \%$ oil, $24.2 \%$ gas, and $27 \%$ coal. Renewables only made up $5 \%$ (excluding hydro but including biofuels), while hydro accounted for $6.4 \%$ and nuclear for $4.3 \%{ }^{31}$ As far as electricity generation is concerned, in 2019 coal remained the single largest source of power while renewables increased their share in generation from $9.3 \%$ to $10.4 \%$, overtaking nuclear generation for the first time. ${ }^{32}$

Meanwhile, в р has provided three scenarios regarding emissions reduction to 205 o. They are: the Rapid Transition Scenario ('Rapid'); the Net Zero Scenario ('Net Zero'); and Business-as-usual Scenario ('BAU'). Under 'Rapid', there will be a significant increase in carbon prices, supported by sector-specific measures, causing energy-related $\mathrm{CO}_{2}$ emissions from energy use to fall around $70 \%$ by 2050. This will limit the rise in global temperatures by 2100 to well below $2^{\circ} \mathrm{C}$ above pre-industrial levels, consistently with the Paris Agreement. With 'Net Zero', shifts in societal behaviour and preferences and additions to 'Rapid' will accelerate emissions reduction. $\mathrm{CO}_{2}$ emissions from energy use will fall by over $95 \%$ by 205 , consistently with limiting temperature rises to $1.5^{\circ} \mathrm{C}$. With 'BAU', there will be slow progress with government policies, technologies and social preferences as seen in the recent past. $\mathrm{CO}_{2}$ emissions will peak in the mid2020 but there will not be a significant decrease in emissions from energy use. By 2050 , emissions will be less than $10 \%$ below 2018 levels. ${ }^{33}$

Given that not even the 'BAU' scenario of emissions peaking by 2020 has been realised, it will take extraordinary efforts to achieve with the 'Rapid' or 'Net Zero' scenarios and meet the Paris temperature goal.

30 Available at <https://www.bp.com/content/dam/bp/business-sites/en/global/corporate/ pdfs/energy-economics/statistical-review/bp-stats-review-202o-full-report.pdf>.

$31 \quad$ Ibid., at 4.

$32 \quad$ Ibid., at 7 .

33 See <https://www.bp.com/en/global/corporate/energy-economics/energy-outlook/intro duction/overview.html>. 
The International Monetary Fund (IMF) has released its World Economic Outlook: April 2020:The Great Lockdown, ${ }^{34}$ quantifying the economic impacts of CoviD-19. As the IMF states, " $[\mathrm{t}]$ his is a truly global crisis as no country is spared ... developing economies face additional challenges with unprecedented reversals in capital flows as global risk appetite wanes.' ${ }^{35}$ In June 2020, the IMF released an updated report A Crisis Like No Other, An Uncertain Recovery, ${ }^{36}$ which forecasted global growth for 2020 at $4.9 \%$, which is 1.9 percentage points below previous forecasts. Recovery from the pandemic is projected to be slower with global growth in 2021 projected at only $5.4 \%$, meaning that $2021 \mathrm{GDP}$ would be 6.5 percentage points lower than the preCOVID-19 projections of January 2020. Low-income households will be acutely impacted, undermining global efforts since the 199os to reduce extreme poverty. This is significant given the 2019 report of the Special Rapporteur for Extreme Poverty that climate change represents an emergency without precedent which will have devastating consequences for people in poverty. He stated that:

[e]ven under the best-case scenario, hundreds of millions will face food insecurity, forced migration, disease and death. Climate change threatens the future of human rights and risks undoing the last 50 years of progress in development, global health and poverty reduction. ${ }^{37}$

In December 2020, the Global Carbon Project (GCP) reported that given CoviD-19 lockdowns around the world, $\mathrm{CO}_{2}$ emissions from fossil fuel and industry in 2020 would fall by $7 \%$. This is the largest absolute annual decline ever recorded and the largest relative fall since the World War II. For example, in all the world's biggest emitters, estimates are that emissions will have fallen $12 \%$ in the US, $11 \%$ in the EU, $9 \%$ in India and $1.7 \%$ in China. While this is unlikely to slow the pace of global warming, the GCP confirms that long-term emissions cuts can be followed by aligning economic recovery with action

\footnotetext{
34 Available at <https://www.imf.org/en/Publications/WEO/Issues/2020/04/14/weo-april $-2020>$.

35 Available at <https://blogs.imf.org/2020/04/14/the-great-lockdown-worst-economic-down turn-since-the-great-depression/>.

36 Available at $<$ https://www.imf.org/en/Publications/WEO/Issues/2020/o6/24/WEOUpdate June2O2O >.

37 Available at <https://www.ohchr.org/EN/Issues/Poverty/Pages/ClimateChange.aspx >.
} 
on climate change. ${ }^{38}$ The wMO's 2020 report, discussed above, has a rather different interpretation stating that the temporary reduction in emissions in 2020 resulting from COVID-19 likely indicates a slight decrease in the annual growth rate of $\mathrm{CO}_{2}$ concentrations in the atmosphere but which is almost indistinguishable from the natural interannual variability driven largely by the terrestrial biosphere. ${ }^{39}$

Meanwhile, the December 2020 UNEP Emissions Gap Report 2020 reports that CoviD-19 reduction in global emissions is only short term and will not contribute significantly to emissions reductions by 2030 without strong decarbonization policies in the economic rescue and recovery measures. New or updated NDCs and long-term mitigation strategies must also be available for the reconvened COP 26 in Glasgow in November 2021. ${ }^{40}$

Consequently, although Covid-19 is likely to deliver a temporary reduction in emissions, and hopefully some longer-term reductions if nations transition to a green economy, it is necessary to confront the climate emergency. The climate emergency exacerbates all countries' vulnerability and exposure to extreme events and disasters.

\section{$5 \quad$ What Has the Paris Agreement Delivered?}

The multilateral climate change negotiations under the UNFCCC have been underway now for twenty-eight years. ${ }^{41}$ The ultimate objective of the UNFCCC is to achieve 'stabilization of greenhouse gas concentrations in the atmosphere at a level that would prevent dangerous anthropogenic interference with the climate system. Such a level should be achieved within a time-frame sufficient to allow ecosystems to adapt naturally to climate change, to ensure that

38 See <https://www.carbonbrief.org/global-carbon-project-coronavirus-causes-record-fall -in-fossil-fuel-emissions-in-202O>. For an earlier GCP report see Corinne Le Quéré et al., 'Supplementary data to: Le Quéré et al (2020), Temporary reduction in daily global $\mathrm{CO}_{2}$ emissions during the COVID-19 forced confinement (Version 1.0) (Global Carbon Project: 2020) <https://doi.org/10.1816o/RQDW-BTJU> available at <https://www.icos-cp.eu/gcp -covidig>.

$39 \quad$ कмо (n 18$) 5$.

40 See <https://wedocs.unep.org/bitstream/handle/20.500.11822/34438/EGR2oESE.pdf? sequence $=25>$, vi.

41 For an extensive summary of this history see Rosemary Lyster, Climate Justice and Disaster Law (Cambridge University Press 2015). See also Rosemary Lyster, 'Climate Change Law (2018)' (2019) 1 Yearbook of International Disaster Law 388-397, where the Paris Agreement and the negotiations at the Twenty Fourth Conference of the Parties to the UNFCCC in 2018 are discussed. 
food production is not threatened and to enable economic development to proceed in a sustainable manner'.42 The Paris Agreement came into force on 4 November $2016^{43}$ and a work program has been established to progressively deliver the key outcomes of the Agreement. ${ }^{44}$ The most recent negotiations under the UNFCCC took place in Madrid at the Twenty Fifth Conference of the Parties to the UNFCCC (COP 25) from 2-13 December 2019. The Twenty Sixth Conference of the Parties (COP 26) scheduled to take place in 2020 was postponed due to the effect of COVID-19. The negotiations will be held in Glasgow in November 2021.

\subsection{A Summary of the Paris Agreement}

Under the Paris Agreement, the Parties agreed to 'hold the increase in the global average temperature to well below $2^{\circ} \mathrm{C}$ above pre-industrial levels and to pursue efforts to limit the temperature increase to $1.5^{\circ} \mathrm{C}$ above pre-industrial levels, to significantly reduce the risks and impacts of climate change. ${ }^{45}$ Most of the details for implementing the Paris Agreement - known as 'the Paris Rulebook' - are encompassed in the COP 24 'Katowice climate package' 46 but are too extensive to be reproduced here. Under the Agreement, developed and developing country Parties must prepare, communicate and implement successive voluntary nationally determined contributions (NDCs), which will be pursued through domestic mitigation measures. Countries must regularly update and improve upon previous NDC and each successive commitment must reflect their highest possible ambition, in accordance with its common but differentiated responsibilities and respective capabilities, and in the light of different national circumstances. Countries must communicate their new NDCs every 5 years and be informed by a Global Stocktake, the first of which will be undertaken in 2023 and every five years thereafter. ${ }^{47}$

The Paris Agreement establishes a global adaptation goal which aims to: enhance adaptive capacity; strengthen resilience; and reduce vulnerability to climate change. ${ }^{48}$ All Parties must prepare a National Adaptation Plan

$42 \quad$ Paris Agreement (n 2) para. 2.

43 See <http://newsroom.unfccc.int/unfccc-newsroom/landmark-climate-change-agreement -to-enter-into-force/>.

44 See Progress tracker Work programme resulting from the relevant requests contained in decision 1/CP.21 available at <https://unfccc.int/sites/default/files/resource/pa_prog ress_tracker_20o617.pdf >.

45 Paris Agreement (n 2) para. 2(a).

46 Available at $<$ https://unfccc.int/process-and-meetings/the-paris-agreement/paris-agree ment-work-programme/katowice-climate-package $>$.

47 Paris Agreement (n 2) para. Art. 14(2).

$48 \quad$ Ibid., para. $7(1)$. 
and implement the agreed upon adaptation actions. Overall progress with achieving this global goal is part of the Global Stocktake. ${ }^{49}$ The Agreement also endorses the permanence of the Warsaw international mechanism for loss and damage associated with climate change impacts (the WIM) including extreme events and slow onset events, in developing countries that are particularly vulnerable to the adverse effects of climate change..$^{50}$ In this regard, the Agreement requires Parties to take further action on aspects such as early warning systems, risk insurance facilities, climate risk pooling and other insurance solutions. However, and very significantly, the Parties have decided ${ }^{51}$ that the Agreement does not involve or provide a basis for any liability or compensation for the impacts of climate change. Paragraph $5^{\circ}$ of the Decision Adopting the Paris Agreement ${ }^{52}$ requested the Executive Committee of the WIM to establish a Task Force on Displacement (TFD).

Article 9 of the Paris Agreement makes it absolutely clear that '[d]eveloped country Parties shall provide financial resources to assist developing country Parties with respect to both mitigation and adaptation in continuation of their existing obligations under the Convention'. Developed countries agreed to provide US $\$ 100$ billion per year to 2020 . This confirms the funding promises made by the Parties under the 2010 Cancun Agreements to provide the same amount of funding between 2010-2020.

\section{What Has the Paris Agreement Delivered in 2020?}

\subsection{The Parties to the UNFCCC and the Paris Agreement Express Concern} Given that the COP 26 negotiations did not proceed due to Covid-19, we need to still refer to the decisions taken at COP $25 .{ }^{53}$ There the Parties to the UNFCCC noted their concern at the state of the global climate system ${ }^{54}$ and re-emphasized 'with serious concern the urgent need to address the significant gap' between the Parties' mitigation efforts and the agreed temperature goal, ${ }^{55}$ mentioned above. They also recalled the need for significant adaptation

\footnotetext{
49 Ibid., para. $7(14)$.

$5^{\circ}$ Decision 2/CP.19, FCCC/CP/2013/10/Add.1, at <http://unfccc.int/resource/docs/2013/ copig/eng/1oaor.pdf>.

$51 \quad$ Paris Agreement (n 2) para. 51.

52 Decision Adopting the Paris Agreement ( $(\mathrm{n} 3)$.

53 Decision 1/CP.25 Version 14/12/2019 07:59 Proposal by the President, at <https://unfccc .int/sites/default/files/resource/DT.COP25.i18.3.pdf >.

54 Ibid., para. 3 .

$55 \quad$ Ibid., para. 8.
} 
which could be offset by enhanced mitigation ${ }^{56}$ and the urgency to enhance ambition in both areas. ${ }^{57}$ The Parties also recalled the commitment made by developed country Parties under the Paris Agreement to jointly mobilize USD 100 billion per year by 2020 to assist developing countries' climate change efforts. They noted the ongoing concern that developing countries face continued challenges in accessing financial, technology and capacity-building support. ${ }^{58}$ The role of nature in addressing climate change and its impacts was also recognised as well as the need to address biodiversity loss and climate change in an integrated manner. ${ }^{59}$ The imperatives of a just transition of the workforce and the creation of decent work and quality jobs in accordance with nationally defined development priorities was also recalled. ${ }^{60}$ The Parties welcomed the continuation of the Marrakech Partnership for Global Climate Action, which supports climate change collaborations between national and subnational governments, businesses and investors. They called on the highlevel champions, who lead this initiative, to explore ways for enhancing the actions of the Parties and non-Party stakeholders. ${ }^{61}$ It is clear that the Parties are concerned that actions required under the Paris Agreement are not being undertaken with sufficient urgency. Unfortunately, as the ensuing discussion shows, that concern is not being put into meaningful action.

\subsection{Emissions Reduction and the Global Temperature Goal}

After 28 years of negotiating under the UNFCCC and more recently the Paris Agreement, the task of meeting the temperature goal seems out of reach at present, as confirmed by the reports discussed above. It must be concluded that at present the targets remain out of reach. At COP 25, the Parties decided that in the second half of 2020 and concluding at COP 28 in 2022 the second periodic review ${ }^{62}$ will take place, on the basis of the best available science. It will assess the aggregated effect of the steps taken by Parties to achieve the agreed long term climate goal; ${ }^{63}$ and will not result in any alteration or redefinition of this goal. ${ }^{64}$

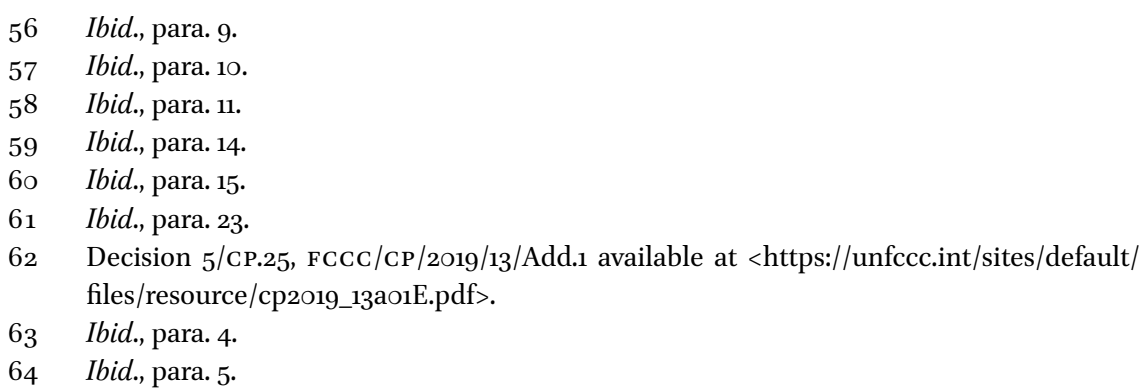


2020 was the year, under the Paris Agreement, for countries to update and strengthen their Nationally Determined Contributions committed to in 2015 . According to the NDC Registry, while 192 countries have submitted their first NDC, by December 2020 only nine countries had submitted their second NDC. ${ }^{65}$ One of those is the European Union. The EU's first NDC committed to a binding target of at least $40 \%$ domestic reduction in greenhouse gas emissions by 2030 compared to $1990 .{ }^{66}$ In September 2020 , the European Commission announced in it policy document 'Stepping up Europe's 2030 climate ambition: Investing in a climate-neutral future for the benefit of our people'67 that the EU's new 203 o target would be emissions reduction of $55 \%$ by 2030 , compared to 1990 levels. ${ }^{68}$ In December 2020, the EU submitted its updated NDC signalling that it would objective of achieving a climate-neutral EU by 2050. ${ }^{69}$ The United States' first NDC under the Paris Agreement was 26-28\% below its 2005 level in 2025 and to make best efforts to reduce its emissions by 28\%.70 In April 2020, upon the US re-joining the Paris Agreement, President Biden announced that the US's new target was $50-52 \%$ reduction compared with 2005 levels by $2030 .{ }^{71}$ Norway has also submitted its second NDC. The first intended to reduce emissions by at least $40 \%$ compared to 1990 by $2030 .{ }^{72}$ Norway's second NDC intends to reduce emissions by at least $50 \%$ and towards $55 \%$ compared to 1990 levels by $2030 .{ }^{73}$ Although not formally submitted on the NDC Registry, in September 2030 President Xi Jinping announced that China will strengthen its 2030 climate target (NDC), peak emissions before

65 See $<$ https://www4.unfccc.int/sites/ndcstaging/pages/Party.aspx?party=EUU\&proto type $=1>$.

66 See $<$ https://www4.unfccc.int/sites/ndcstaging/PublishedDocuments/European\%2o Union\%2oFirst/LV-o3-o6-EU\%2oINDC(Archived).pdf>.

67 See $<$ https://eur-lex.europa.eu/legal-content/EN/TXT/HTML/?uri=CELEX:52O2oDCo562 \&from $=\mathrm{EN}>$.

68 Ibid., para 1.

69 See <https://www4.unfccc.int/sites/ndcstaging/PublishedDocuments/European\%2O Union\%2oFirst/EU_NDC_Submission_December\%202020.pdf >.

70 See <https://www4.unfccc.int/sites/ndcstaging/PublishedDocuments/United\%2oStates \%20of\%2oAmerica\%2oFirst/U.S.A.\%2oFirst\%2oNDC\%2oSubmission.pdf>.

71 See <https://www.whitehouse.gov/briefing-room/statements-releases/2021/04/22/fact-sheet -president-biden-sets-203o-greenhouse-gas-pollution-reduction-target-aimed-at-creatinggood-paying-union-jobs-and-securing-u-s-leadership-on-clean-energy-technologies/>.

72 See <https://www4.unfccc.int/sites/ndcstaging/PublishedDocuments/Norway\%2oFirst/ NorwayINDC\%2O(Archived).pdf $>$.

73 See <https://www4.unfccc.int/sites/ndcstaging/PublishedDocuments/Norway\%20First/ Norway_updatedNDC_2020\%2O(Updated\%2osubmission).pdf>. 
2030 and aim to achieve carbon neutrality before 2060. ${ }^{74}$ China's first NDC ${ }^{75}$ committed to the following actions by 2030 : to achieve the peaking of carbon dioxide emissions around 2030 and making best efforts to peak early; to lower carbon dioxide emissions per unit of GDP by $6 \circ \%$ to $65 \%$ from the 2005 level; to increase the share of non-fossil fuels in primary energy consumption to around $20 \%$; and to increase the forest stock volume by around 4.5 billion cubic meters on the 2005 level.

\subsection{The Adaptation Goal}

The Adaptation Committee has developed six workstreams: coherence and collaboration; gender; regional centres and networks on adaptation; technical support and guidance; means of implementation; and communication and outreach. ${ }^{76}$ It has also established a Task Force on National Adaptation Plans and it has developed work plans for 2016-2018 and 2019-2021. ${ }^{77}$ At COP 25, the Parties recalled the need for significant adaptation which could be offset by enhanced mitigation ${ }^{78}$ and the urgency to enhance ambition in both areas. ${ }^{79}$ Be that as it may, as discussed below regarding climate finance, developing country efforts to adapt to extreme events and disasters will only be as effective as the finance flowing to them. It is woefully insufficient and showing no signs of improvement.

\subsection{Report of the Executive Committee of the Warsaw International Mechanism (WIM) for Loss and Damage Associated with Climate Change Impacts ${ }^{80}$}

Following Paris, an Executive Committee (Exco) of the WIM was established and has developed a five-year rolling work plan ${ }^{81}$ to address the loss and

74 See $<$ https://climateactiontracker.org/countries/china/>.

75 See <https://www4.unfccc.int/sites/ndcstaging/PublishedDocuments/China\%2oFirst/ China\%27s\%2oFirst\%2oNDC\%2oSubmission.pdf>.

76 See $<$ https://unfccc.int/process-and-meetings/bodies/constituted-bodies/adaptation -committee-ac/areas-of-work-adaptation-committee\#eq-3>.

77 See <https://unfccc.int/process-and-meetings/bodies/constituted-bodies/adaptation -committee-ac/areas-of-work/ac-s-task-force-on-national-adaptation-plans-nap-task force $>$.

78 Ibid., para. 9 .

79 Ibid., para. 10.

8o FCCC/SB $/ 2019 / 5$, available at <https://unfccc.int/sites/default/files/resource/sb2O19_O5E .pdf $>$.

81 Available at <https://unfccc.int/sites/default/files/resource/Detailed\%2oworkplan\%2O by\%2ostrategic\%2oworkstreams.pdf>. 
damage associated with extreme weather events and slow onset events. ${ }^{82}$ The efforts of the Executive Committee (Excom) ${ }^{83}$ in 2018-2019 have centred on: (a) Slow onset events, (b) Non-economic losses, (c) Comprehensive risk management approaches (d) Human mobility, including migration, displacement and planned relocation, and (e) Action and support, including finance, technology and capacity building to address loss and damage associated with the adverse effects of climate change. In 2019, it established the Technical Expert Group on Comprehensive Risk Management to assist it with implementing this Workstream. ${ }^{84}$

However, it is fairly clear that the Parties to the Paris Agreement are not entirely satisfied with the work of the Committee. ${ }^{85}$ They agree that it needs further guidance to improve 'its timeliness, relevance, visibility, coherence, complementarity, comprehensiveness, responsiveness and resourcing and the delivery and usefulness of its products and outputs.' ${ }^{86}$ Parties are also encouraged to establish a loss and damage contact point through their respective national focal points. ${ }^{87} \mathrm{~A}$ new body, the Santiago Network, was established to catalyse technical assistance in developing countries that are particularly vulnerable to the adverse effects of climate change. ${ }^{88}$ The Excom is also encouraged to draw upon the work of international processes, such as the 2030 Agenda for Sustainable Development and the Sendai Framework for Disaster Risk Reduction 2015-2030.89

The 2020 Report of the WIM Excom ${ }^{90}$ notes the following actions:

- Slow onset events and non-economic losses

The Excom has commissioned and published a special issue of Current Opinions in Environmental Sustainability to enhance research on slow

\footnotetext{
$82 \quad$ Ibid., para. 25 .

83 Ibid., Part III.

84 See Report of the Executive Committee of the Warsaw International Mechanism for Loss and Damage associated with Climate Change Impacts, FCCC $/ \mathrm{sB} / 2019 / 5$ available at $<$ https://unfccc.int/sites/default/files/resource/sb2019_o5E.pdf>.

85 FCCC/PA/CMA/2019/L.7, available at <https:/unfccc.int/documents?f\%5B०\%5D=con ference $\%{ }_{3} \mathrm{~A}_{42} 5_{2} \&$ search $2=\&$ search $3=\&$ page $=\%{ }_{2} \mathrm{C} \%{ }_{2} \mathrm{C}_{3}>$.

86 Ibid., para. 7 .

87 Ibid., para. 13 .

88 Ibid., para. 43 .

89 Ibid., para. 22.

$90 \quad$ FCCC $/ \mathrm{sB} / 2020 / 3$, available at <https://unfccc.int/sites/default/files/resource/sb2O2O _o3E.pdf >.
} 
onset events. ${ }^{91}$ In 2020, the Excom also established the Expert Groups on slow onset events ${ }^{92}$ and non-economic losses. ${ }^{93}$ Both of these will establish their Rolling Plan on Action in 2021.

\section{- Comprehensive risk management approaches}

The Excom and the Technology Executive Expert Committee have jointly released a Policy Brief on technologies for averting, minimizing and addressing loss and damage in coastal zones. The Brief notes that over 600 million people currently live in a coastal zone less than 10 metres above sea level. Also, almost $60 \%$ of the world's cities with populations of 5 million people are only $100 \mathrm{kms}$ from the coastline. As evidenced recently in many coastal areas, sea-level rise and extreme weather events are causing extensive losses and damages. A recent technology needs assessment shows that one third of developing countries prioritise the need for technologies to protect infrastructure in coastal zones, including both hard and soft measures. ${ }^{94}$ Consequently, the Brief provides information on hardware, software and orgware technologies to assess risks, reduce them, recover from them and rehabilitate the coastal zone. It analyses the strengths and weaknesses of these technologies and indicates where improvements can be made to assist countries to deal with the adverse effects of climate change. ${ }^{95}$

To assist developing countries with risk profiling, observation and risk assessment in the context of loss and damage, and risk management approaches, the Excom convened a Technical Expert Group on Comprehensive Risk Management (TEG-CRM).${ }^{96}$ It has developed a Plan

91 Ibid., para. 24, see also Susan Adamo et al. (eds.) Slow Onset events related to Climate Change (2021) 50 Special Issue 'Current Opinions in Environmental Sustainability', available at $<$ https://www.sciencedirect.com/journal/current-opinion-in-environ mental-sustainability/vol/5o/suppl/C >.

92 Ibid., para. 25. See also <https://unfccc.int/process/bodies/constituted-bodies/WIM ExCom/SOEs>.

93 Ibid., para. 27. See also <https://unfccc.int/process/bodies/constituted-bodies/WIM ExCom/NELs $>$.

94 For an extensive discussion of climate change adaptation in the coastal zone see Lyster, Climate Justice (n 41) Chapter 4 at 198-206.

95 Ibid., para. 30. See also POLICY BRIEF Technologies for Averting, Minimizing and Addressing Loss and Damage in Coastal Zones (WIM Exco, TEC: 2020) available at $<$ https://unfccc.int/ttclear/misc_/StaticFiles/gnwoerk_static/202O_coastalzones/bge88f6 fea374d8aa5cb44115d20116o/3863c9fabdf74ea49710189acbf69o7a.pdf>.

Ibid., para. 31 . 
of Action 2019-2021 ${ }^{97}$ and the Excom notes that comprehensive risk management facilitates collaboration with stakeholders engaged with climate change adaptation and disaster risk management. Meanwhile, the pandemic has highlighted the interaction and interconnectedness of multiple risks and cascading impacts on vulnerable communities and countries, such as health and climate change. ${ }^{98}$

\section{- The Fiji Clearing House for Risk Transfer}

As mentioned above, the Paris Agreement denies compensation to the victims of climate change and rather requires Parties to enhance their understanding of 'risk insurance facilities, climate risk pooling and other insurance solutions' - in other words private sector responses. However, a real question is the reliability of the insurance system at a time when the world has witnessed, and is likely to continue witnessing, a series of catastrophic climate extremes. ${ }^{99}$ Moreover, in the author's view, the Paris Agreement provisions are just 'words on a page'. They bear no relation whatsoever to the very significant barriers developing countries face in relying on insurance as a compensation mechanism. Insurance penetration even in developed countries is very low and it is even worse in developing countries. ${ }^{100}$ Households and businesses in lowand middle-income countries are beginning to access new index-based microinsurance. However, this is likely to reach only a small fraction of risk-prone households. ${ }^{101}$

The Fiji Clearing House for Risk Transfer was established in 2017 at COP 23 to provide information on insurance and risk transfer. The Excom reports that as at 11 November 2020, the Clearing House contained information on 85 institutions, 41 case studies and 29 tutorials. The Excom, in partnership with the secretariat of the InsuResilience Global Partnership,

Available at <https://unfccc.int/sites/default/files/resource/TEG-CRM\%2oPlan\%2oof\% 2oAction_Approved\%2oversion.pdf $>$.

98 Ibid., para. 34 .

99 See World Resources Institute in Collaboration with U.N. Development Programme, U.N. Environment Programme, \& World Bank, Decision Making in a Changing Climate: Adaptation Challenges and Choices (2011), available at $<$ http://pdf.wri.org/world_resour ces_report_2010-2011.pdf>.

100 For a full analysis of this see Howard Kunreuther and Rosemary Lyster, 'The Role of Public and Private Insurance in Reducing Losses from Extreme Weather Events and Disasters' (2016) 19 Asia Pacific Journal of Environmental Law 29-54 and Lyster, Climate Justice (n 41) Chapter 5 .

101 Ibid., 125. 
maintains RISK TALK, an artificial intelligence interactive feature which connects those looking for tailored solutions with risk transfer expertise. As at 11 November 2020, 153 specific questions had been posted and 190 responses provided via the RISK TALK platform. ${ }^{102}$

Clearly, the facility is enhancing the dissemination of information on insurance but the author doubts that this is in any way ameliorating the problems faced by developing countries in insuring themselves against extreme events and disasters. Is this really what developing countries need in a climate emergency?

\subsection{The Task Force on Displacement: Human Mobility}

A key working group of the WIM Excom is the Task Force on Displacement (TFD), established under the Paris Agreement. ${ }^{103}$ At COP 24, the Excom made extensive recommendations ${ }^{104}$ on averting, minimizing and addressing displacement based on the TFD's report comprising eighty-two pages. ${ }^{105}$ The TFD reported that between 2008 and $2016,86 \%$ of internal displacements were as a result of weather events accounting for a total 195 million displacements. Of these hydrometeorological events, floods accounted for $52 \%$ of displacements followed by storms at $32 \%$ per cent. ${ }^{106}$ In addition to containing a list of recommendations, this report includes detailed summary reports on the activities of the Task Force on Displacement's work plan, making it essential reading for those working in this area. In 2019, the TFD provided an update ${ }^{107}$ on the implementation of all of its activities to COP 25 .

\footnotetext{
102 Ibid., para. 37.

103 For the author's publications on climate-induced displacement see Rosemary Lyster and Maxine Burkett 'Climate-induced displacement and climate disaster law: barriers and opportunities' in Rosemary Lyster and Robert M. Verchick (eds.) Research Handbook on Climate Disaster Law: Barriers and Opportunities (Edward Elgar 2018) 97-113 and Rosemary Lyster, 'Protecting the human rights of climate displaced person: the promise and limits of the United Nations Framework Convention on Climate Change' in Anna Grear and Louis Kotze (eds) Research Handbook on Human Rights and the Environment (Edward Elgar 2015) 423-448.

104 For details on this see Rosemary Lyster, Climate Change Law (n 41) 388-397.

105 Available at <https://environmentalmigration.iom.int/sites/default/files/2018_TFD_report _16_Sep_FINAL-unedited.pdf >.

106 Ibid., para. 123.

107 Available at <https://unfccc.int/process-and-meetings/bodies/constituted-bodies/execu tive-committee-of-the-warsaw-international-mechanism-for-loss-and-damage-wimexcom/task-force-on-displacement/implementation-updates-task-force-on-displace ment\#eq-2>.
} 
As at September 2019, the membership of the $\mathrm{TFD}^{108}$ is: the Least Developed Countries (LDC) Expert Group; the WIM Excom (Loss and Damage); the United Nations Development Program and the International Labour Organization (Development); the United Nations Human Rights Commission and the International Federation of Red Cross and Red Crescent Societies (Humanitarian); the IOM and the Platform on Disaster Displacement (Human Mobility); Youngo and the Advisory Group on Climate Change and Human Mobility (Civil Society); and the Adaptation Committee (Adaptation). This is an impressive collection of organisations which works together across issues and disciplines.

In 2O2O, the TFD highlighted that the COVID-19 pandemic and associated recovery makes it difficult to keep displacement relevant and high on the list of shifting priorities. However, a tripartite research initiative has begun on COVID-19's impact on the nexus between climate change, labour markets and migration in South Asia, as well as on issues relating to the COVID-19 humanitarian response. ${ }^{109}$ Despite COVID-19, virtual capacity-building and training activities have progressed. For example, e-learning disaster displacement guidelines for the Central American and Caribbean regions have been developed, and online training for Pacific Island countries on governing labour migration will occur. ${ }^{110}$ The TFD has also been briefed by the Special Rapporteur on the human rights of internally displaced persons on her July 2020 Report on internal displacement in the context of the slow-onset adverse effects of climate change, ${ }^{111}$ which was submitted to the United Nations General Assembly. This Report notes that over the coming years and decades climate-induced internal displacement is expected to increase significantly. Without concrete climate and development action, over 143 million people in sub-Saharan Africa, South Asia and Latin America could be forcibly displaced internally by 2050 as a result of the slow-onset impacts of climate change. The Special Rapporteur also reports that disaster displacement is included in the Plan of Action for Advancing Prevention, Protection and Solutions for Internally Displaced People for the period 2018-202O, ${ }^{112}$ led by her and developed jointly with the Office of the United Nations High Commissioner for Refugees and the Office for the Coordination of Humanitarian Affairs, in 2017. She also welcomes the establishment in October 2019 of the High-level Panel on Internal Displacement, ${ }^{113}$

\footnotetext{
$108 \mathrm{FCCC} / \mathrm{sB} / 2 \mathrm{O19} / 5$, Figure 1 at 8 available at $<$ https://undocs.org/FCCC/SB/2019/5>.

109 WIM Excom (n 9o) para. 43.

110 Ibid., para. 42.

$111 \mathrm{~A} / 75 / 207$ available at $<\mathrm{https} / /$ undocs.org/A/75/207>.

112 Available at $<$ https://www.globalprotectioncluster.org/gp2o/>.

113 See <https://www.un.org/internal-displacement-panel/>.
} 
established by the Secretary-General. This Panel will assess internal displacement within the frame of disasters and the adverse effects of climate change. Her hope is that her 2020 Report can inform the Panel's work. ${ }^{114}$

An important observation by the TFD is that the Green Climate Fund, discussed below, does not make explicit reference to climate-induced human mobility in terms of its objective which might hinder the possibility of finance on a large scale. ${ }^{115}$ If there is no international funding for the relocation and resettlement of CDPs then the administrative and financial burden falls on domestic governments to manage international displacements, or on those governments that are managing cross-border displacements.

\subsection{Action and Support}

In 2020, the Excom established a new Action and Support Experts Group which will commence its activities in 2021. ${ }^{116}$ As discussed below, accessing funding for actions under the WIM has proved extremely difficult. The Excom reports that it has been in discussions with the Green Climate Fund (GCF) and the GCF advised countries to access resources available through its Readiness and Preparatory Support Programme ${ }^{117}$ for work on comprehensive risk management, which would enhance their ability to develop and submit project proposals related to loss and damage.

In 2020, the Excom also organized a half-day workshop with the Paris Committee on Capacity-building ${ }^{118}$ which has identified the specific needs of developing countries with regard to observation and risk assessment in the context of loss and damage. These include: Impact thresholds and science (addressing future changes); Comprehensive risk management (develop methodologies); Translating climate models (scaling climate change data up and down from the local to the global); Availability of observation data (harmonizing loss and damage data); Institutional responsibilities (building legal environments to share data); and Communication (between the climate, disaster and Humanitarian communities). ${ }^{119}$

In 2020, the Excom and the Paris Committee on Capacity-building organized a half-day event on loss and damage at the 2nd Capacity-building Hub at

\footnotetext{
114 Ibid., para. I.3.

115 TFD Report (n 105) para. 81(c)(b).

116 WIM Excom (n 9o) para. 47; see <https://unfccc.int/process/bodies/constituted-bodies/ WIMExCom/Action-Support $>$.

117 See <https://www.greenclimate.fund/sites/default/files/document/readiness-guidebook -1.pdf $>$.

118 See <https://unfccc.int/pccb>.

119 WIM Excom (n 9o) para. 54 and see Figure 1.
} 
COP 25, aiming to strengthen dialogue and coordination among stakeholders and to provide information on capacity needs identified in implementing the workplan of the Excom. Such needs include those related to observation and risk assessment in the context of loss and damage, which were considered at a workshop organized by the TEG-CRM. ${ }^{120}$

\subsection{The Ongoing Funding Crisis}

It is very difficult to project the loss and damage that developing countries will experience in future as a result of extreme events and disasters, and the costs of mitigation and adaptation in those countries. In October 2019, the Grantham Institute ${ }^{121}$ estimated that in a scenario where global warming remains below $2{ }^{\circ} \mathrm{C}$ and USD 200 billion-worth of adaptation measures are in place, the losses start at USD 400 billion per year by 2030 . The costs could grow to USD 4 trillion per year if the Earth experiences over $5.3^{\circ} \mathrm{C}$ of warming by $2100 .{ }^{122}$ Given these staggering figures, the climate finance currently available to developing countries is entirely insufficient.

At COP 25, the Parties noted their ongoing concern that developing countries face continued challenges in accessing financial, technology and capacitybuilding support. ${ }^{123}$ This is because pledges to the Green Climate Fund as at 3 O April 2019 amounted to only USD 10.3 billion equivalent, of which $99 \%$ has been converted into contribution agreements/arrangements. However, in its 2020 report the GCF states that COVID-19 has had an impact on contributions from developed countries. Although the pledged amount for 2020 amounted to USD 9.99 billion only USD 7.46 billion has been confirmed. ${ }^{124}$ Nevertheless, as at 16 November 2020, the GCF had approved 159 funding proposals stands at 159 , and the total amount of GCF funding is USD 7.2 billion, with USD 16 billion of co-financing expected. It is expected that these projects and programmes will abate a total of 1.2 billion tonnes of carbon dioxide equivalent (tCO2eq) of greenhouse gas (GHG) emissions. ${ }^{125}$

\footnotetext{
120 Idem.

121 Rebecca Byrnes and Swenja Surminski, 'Addressing the impacts of climate change through an effective Warsaw International Mechanism on Loss and Damage Submission to the second review of the Warsaw International Mechanism on Loss and Damage under the UNFCCC' (Grantham Institute: October 2019) available at <http://www.lse .ac.uk/GranthamInstitute/wp-content/uploads/2019/10/GRI_Addressing-the-impacts -of-climate-change-through-an-effective-Warsaw-International-Mechanism-on-Loss -and-Damage-1.pdf (accessed 2 July 2020)>.

122 Ibid., at 3-4.

123 Ibid., para. 11.

124 See <https://unfccc.int/sites/default/files/resource/cp2020_o5E.pdf>, para. 21.

125 Ibid., para. 7 .
} 
There are three other sources of funding for adaptation including the Adaptation Fund, established through a levy on the sale of international carbon credits under the Kyoto Protocol market mechanisms; the Least Developed Countries Fund (LDCF) and the Special Climate Change Fund (SCCF) which are managed through the Global Environment Facility (GEF). However, each of these sources of funding is under serious stress about which the author has written extensively elsewhere. ${ }^{126}$ The Adaptation Fund Board's 2020 report ${ }^{127}$ states that, as at 30 June 2020 , cumulative receipts into the Fund amounted to USD 978.32 million, comprising USD 204.74 million from the credits derived under the Clean Development Mechanism, USD 735.25 million from contributions and USD 38.33 million from investment income earned on the Trust Fund balance. Additional contributions were received from Germany, Ireland, Norway, Poland, Spain, Sweden, Switzerland and the Brussels-Capital and Flanders Regions of Belgium amounting to about USD 77.32 million. Unfortunately, a total of USD 21.85 million in pledges had not been received. ${ }^{128}$

In addition to this inadequate funding for mitigation and adaptation activities in developing countries, there is no specific provision for CDPs and nor is funding demarcated for dealing with loss and damage under the WIM. In October 2013, the author ${ }^{129}$ suggested that a fossil fuel-funded Climate Disaster Response Fund be established under the UNFCCC to compensate the victims in developing countries, particularly vulnerable to the impacts of climate change. This Fund, consistently with other liability compensation funds, would place a levy on the world's top two hundred fossil fuel companies as identified by Climate Tracker. ${ }^{130}$ In November 2013, Richard Heede ${ }^{131}$ suggested that the 90 Carbon Majors should pay for adaptation to cover potential climate liability

\footnotetext{
126 Lyster, Climate Justice (n 41) Chapter 6.

127 See FCCC/KP/CMP/2O2O/2-FCCC/PA/CMA/2O2O/2 available at $<$ https://unfccc.int/sites/ default/files/resource/cmp2O2O_O2_cma2O2O_O2E.pdf $>$.

128 Ibid., para. 7 .

129 Rosemary Lyster, 'A Fossil Fuel-Funded Climate Disaster Response Fund under the UNFCCC Loss and Damage Mechanism', first posted on SSRN on 13 October 2013 available at $\langle$ https://papers.ssrn.com/sol3/papers.cfm?abstract_id=2346616 $>$ and published in (2015) 4 Transnational Environmental Law 125-151.

130 'Unburnable Carbon - Are the world's financial markets carrying a carbon bubble' (Climate Tracker: 2013) <https://www.banktrack.org/download/unburnable_carbon/un burnablecarbonfullrev2.pdf $>$.

131 Richard Heede, 'Tracing anthropogenic carbon dioxide and methane emissions to fossil fuel and cement producers, 1854-2010', first published on 13 November 2013 and subsequently as (2014) 122 Climate Change 229-241, at <https://doi.org/10.10o7/ s10584-013-0986-y>.
} 
claims. More recently, in 2019, the Grantham Institute ${ }^{132}$ proposed the establishment of a Loss and Damage finance facility. In other words, there is no shortage of research done and suggestions made as to how to resolve this critical funding deficit.

It should be noted that the financial implications of COVID-19 are likely to be felt well into the future and this affects both the capacity of developing countries to cope, as well as the willingness of developed countries to provide any additional funding for developing countries.

Implementation and Compliance

The Paris Agreement requires an implementation mechanism to be established to consist of a Committee that is expert-based and 'facilitative in nature and function in a manner that is transparent, non-adversarial, and non-punitive'. The Committee will pay particular attention to the respective national capabilities of the countries in meeting their commitments under the Agreement, and any associated failures. ${ }^{133}$ From a legal point of view, this is a weak implementation mechanism as no penalties for non-compliance are mentioned. Rather it is a political and diplomatic mechanisms for "naming and shaming" Parties that do not comply with their NDC, adaptation, and other commitments. The Paris Agreement Implementation and Compliance Committee (PAICC)'s 2020 report notes that it developed a list of elements to be included in the draft rules of procedure with a view to recommending them to COP 26 in Glasgow for consideration and adoption. The Committee also adopted its workplan for 2020 and $2021 .{ }^{134}$ It is too early for the author to comment on the work of this Committee.

\section{8}

\section{The High Level Champions}

It was agreed at COP 21 that two United Nations High Level Champions would be appointed. Their task is to find synergies between government efforts to meet the Paris targets and the many voluntary and collaborative actions being

\footnotetext{
132 Byrnes and Surminski (n 121).

133 Paris Agreement (n 2) para.15.

134 See $<$ https://unfccc.int/sites/default/files/resource/PAICC_2O2OM_2_7_Meeting\%2oreport \%2owith\%2oannexes_final.pdf $>$.
} 
taken by cities, regions, businesses and investors. ${ }^{135}$ In 2019, the Champions and the UNFCCC Secretariat launched Climate Action Pathways ${ }^{136}$ to encourage national and subnational governments and business and investors to work towards the goal of a $1.5^{\circ} \mathrm{C}$ climate resilient world by 2050. Then in June 2020 , they launched Race to Zero ${ }^{137}$ which mobilizes the net zero commitments of a coalition of 733 cities, 31 regions, 3,067 businesses, 173 large investors, and 622 Higher Education Institutions. This program envisages that $20 \%$ of key actors within sectors must commit by COP 26 to transform their activities. They must all commit to the 2023 Global Stocktake and reach net zero by 2050 at the latest, with progress assessed in 2025 and 2030. In 2020, priority metrics were drafted to track progress within these sectors.

The High-Level Climate Champions require all participants to meet a minimum set of common criteria in order to join the Race to Zero challenge. The required procedural steps are set out in the 'Starting Line' criteria while substantive requirements to reach best practice are set out in the 'Leadership Practices'. Starting Line criteria state that the entity must pledge, plan, proceed and publish (which includes reporting publicly on their emissions reduction). The Leadership Practices stipulate that entities must include all emissions including Scope 3 emissions in their targets and must report on whether they are using any sinks or carbon credits to reach their goals. An Expert Peer Review Group advises the Champions whether to admit an entity to the challenge and the Group will also conduct an annual review of performance. ${ }^{138}$

\section{$9 \quad$ Non-State Actors and the Climate Emergency}

There is no doubt that subnational governments, cities, corporations, including the finance sector, non-government organisations and individuals have responded to the temperature goal established under the Paris Agreement. Yet this should not distract the global community from the significant gaps in real action to deal with the Climate Emergency. A report, published in September 2019, titled, 'Global Climate Action from Cities, Regions and Businesses: Impact of Individual Actors and Cooperative Initiatives on Global and National

\footnotetext{
135 See <https://unfccc.int/climate-action/marrakech-partnership/actors/meet-the-champions > .

136 See <https://unfccc.int/climate-action/marrakech-partnership/reporting-and-tracking/cli mate_action_pathways $>$.

137 See <https://unfccc.int/climate-action/race-to-zero-campaign $>$.

138 See $<$ https://racetozero.unfccc.int/wp-content/uploads/2021/o4/Race-to-Zero-Criteria-2.o .pdf $>$.
} 
Emissions, ${ }^{139}$ aggregates climate mitigation commitments reported to some of the world's largest voluntary pledging and reporting platforms. It finds that the commitments 'made by more than 6,ooo cities and regions and 1,5 oo companies in ten of the world's major emitting economies could reduce greenhouse gas ( $\mathrm{GHG}$ ) emissions by 1.2-2 gigatonnes of carbon dioxide equivalent (GtCO2e) per year by 2030 - or roughly $4 \%$ of global emissions today'. These voluntary actions are to be commended but they barely make a dent in the scale of the task ahead.

\section{Conclusions}

This chapter provides a comprehensive overview of what the international negotiations on climate change have delivered. Unfortunately, the picture which emerges is rather bleak. Emissions are not going down and even though the CoviD-19 emergency may result in a temporary slowing of emissions, meeting the Paris temperature goal seems unlikely at present. On the adaptation and Warsaw Mechanism front, funding emerges as a critical ongoing issue. Without funding, developing countries are unlikely to be able to take effective action on mitigation, adaptation and disaster risk reduction. The economic emergency arising out of the COVID-19 lockdowns all around the world make the likelihood of enhanced climate finance even more remote. The international negotiations are crucially important for keeping the goals and vision of the Paris Agreement alive. However, there needs to be far more concrete action, and far more support for the action, on the ground to try to ward off the worst effects of the climate emergency.

139 Available at <https://newclimate.org/2019/og/18/global-climate-action-from-cities-regions -and-businesses-2019/>. 